\title{
Adoption of Instant Messaging for Mathematics Lessons in Rural Schools
}

\author{
Nkhangweni Lawrence Mashau a and Sello Nicolas Mokwena ${ }^{a}$
}

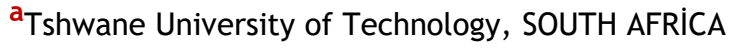

\begin{abstract}
The failure rate of mathematics is significantly high in the South African public secondary schools, particularly in rural areas. South Africa has a deficiency of adequately qualified teachers, particularly in mathematics in rural public schools. A lack of interest in a teaching as a career results in fewer young people taking up teaching as a profession, this contributes to shortage of teachers. Instant messaging applications, specifically Mxit provide a platform which learners and teachers can use for learning mathematics. Mxit which is more popular amoung teenagers who use it for communication with their friends and relatives offers mathematics tutoring through $\mathrm{Dr}$ Math application hosted by the CSIR Meraka Institute in South Africa. The aim of this study was to establish how pupils and teachers in the rural areas where there is a dire shortage of mathematics teacher can take advantage of Dr Math to improve mathematics knowledge and the matric pass rate. Diffusion of innovation theory was used to determine factors that could promote the adoption of instant messaging for learning mathematics in South African rural public schools. Dr Math has not been well promoted among rural schools and therefore lack of its awareness was found as one of the factors hampering learners to adopt it for learning mathematics in South Africa rural public schools.
\end{abstract}

\section{KEYWORDS}

Adoption, Dr Math, Instant Messaging, Learning, Mathematics and Mxit
ARTICLE HISTORY

Received 15 September 2016 Revised 10 November 2016 Accepted 22 February 2017

\section{Introduction}

The failure rate of mathematics is significantly high in the public secondary schools, particularly in rural areas in South Africa (Tachie \& Chireshe, 2013). Graven (2013) indicates that many learners are apprehensive of mathematics as a subject and only few have a passion for numbers and enjoy

\section{CORRESPONDENCE N. L. Mashau $\square$ mashau.lawrence@gmail.com}

(c) 2017 N. L. Mashau and S. N. Mokwena.

Open Access terms of the Creative Commons Attribution 4.0 International License apply. The license permits unrestricted use, distribution, and reproduction in any medium, on the condition that users give exact credit to the original author(s) and the source, provide a link to the Creative Commons license, and indicate if they made any changes. (http://creativecommons.org/licenses/by/4.0/) 
mathematics. Erasmus (2013) indicates that the future of the economy of any country depends on the foundation and understanding of mathematics.

The Department of Education is concerned about the low pass rate of mathematics because it affects the performance of the department at large (General education system quality assessment: Country report South Africa, 2013). The Limpopo Department of Education provides additional classes to Grade 12 learners to improve mathematics results. Teachers of underperforming schools are provided with training during winter and spring school holidays (Limpopo Department of Education, 2011).

South Africa has a deficiency of highly qualified teachers, particularly in mathematics in rural public schools (Graham \& Provost, 2012). A lack of interest in teaching as a career results in fewer young people taking up teaching as a profession; this contributes to a shortage of teachers (Limpopo Department of Education, 2014). Currently the Limpopo Department of Education depends on teachers from neighboring countries to teach subjects such as mathematics in Grade 12 (Limpopo Department of Education, 2011). Technology could be be the answer to how mathematics leaching and leraning may be improved and enable the youth to enjoy mathematics lessons.

Instant messaging (IM) is a set of communication technologies used for text-based communication between two or more participants over the cellular networks. IM is an online chat service which offers real-time text transmission over the cellular network. Instant messaging chat takes place in real time. More advanced instant messaging applications can add file attachments, transfer files, provide clickable hyperlinks, voice chat, and video chat (Kim, Lee, \& Kim, 2014).

Ruan (2013) indicates that instant messaging is a powerful learning environment for learners to exchange knowledge. BBM, WhatsApp, weChat, eBuddy, Viber, Yahoo! Messenger, Google talk, Facebook, Skype, and Mxit are the most used instant messaging applications in South Africa (South African Mobile Report, 2014). The aim of this research was to investigating how the use of Mxit may improve mathematics teaching and learning in Limpopo Province rural public schools. Mxit offers mathematics tutoring through Dr Math, hosted by the CSIR Meraka Institute in South Africa. Mxit is simple and inexpensive and enables the use of a basic cell phone.

Mathematics Pass Rate History

Table 1. National performance in mathematics: 2011-2014 (Limpopo Basic Education, 2014)

\begin{tabular}{|c|c|c|c|c|c|c|c|c|c|c|c|}
\hline \multicolumn{3}{|c|}{2011} & \multicolumn{3}{|c|}{2012} & \multicolumn{3}{|c|}{2013} & \multicolumn{3}{|c|}{2014} \\
\hline 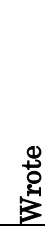 & 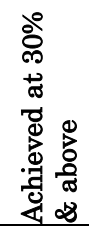 & 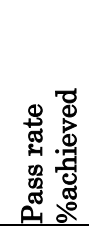 & 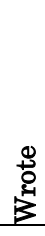 & 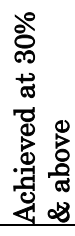 & 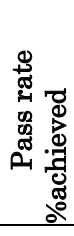 & 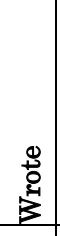 & 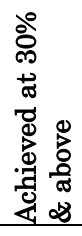 & 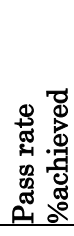 & 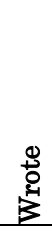 & 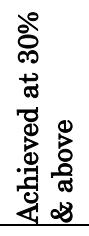 & 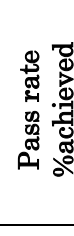 \\
\hline \begin{tabular}{l}
0 \\
0 \\
\multirow{N}{N}{} \\
N
\end{tabular} & $\begin{array}{l}\text { o } \\
0 \\
+ \\
0 \\
\end{array}$ & $\begin{array}{l}\infty \\
0 \\
t^{0}\end{array}$ & $\begin{array}{l}\text { N } \\
\infty \\
\text { o } \\
\text { N }\end{array}$ & 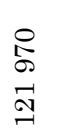 & $\begin{array}{ll}0 \\
\text { in }\end{array}$ & $\begin{array}{l}\text { 吕 } \\
\text { Z }\end{array}$ & 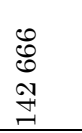 & in & 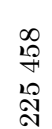 & $\begin{array}{l}\text { I } \\
\text { in } \\
\text { I } \\
\text { I }\end{array}$ & is \\
\hline
\end{tabular}


As indicated in Table 1, in 2011 nationally (224 636) learners wrote mathematics and [104 $033(46.3 \%)]$ learners achieved 30\% and above. In 2012 (225 874) learners wrote mathematics and [121 970 (54.0\%)] learners achieved $30 \%$ and above, whereas in 2013 (241 509) learners wrote mathematics and [142 $666(59.1 \%)$ ] learners achieved $30 \%$ and above. In 2014 nationally (225 458) learners wrote mathematics and [120 523 (53.5\%)] learners obtained $30 \%$ and above. Therefore, South Africa Department of Education achieved an average of 53.2\% mathematics pass rate between 2011 and 2014. As indicated in Table 1, there is a high mathematics failure rate in South African schools in rural areas.

Mathematics education is important to the future of South African. Competence in mathematics is a key requirement in most university faculties. Mathematics impacts on the economic development of South Africa because performance in mathematics in Grade 12 affects production of scarce skills such as, engineering and medicine in the country. Failure to improve in mathematics education is a major problem for the advancement of the economy.

South Africa is a diverse nation, with a population estimated at 54 million people as of July 2014 (Statistics South Africa, 2014). It has been reported that $82 \%$ of South African young people between age of 15 and 24 have cell phones. The young people are early adopters of instant messaging technologies (Beger \& Sinha, 2012).

Learners can utilise IM technology called Mxit Worldwide to learn mathematics on a cell phone by adding Dr Math contacts. They can then participate with other learners in submitting and solving mathematical problems. Learners in rural areas can take advantage of this available way of learning on their cell phones using Mxit application. The cost to download from any mobile phone that allows the use of Mxit, is a minimal rate. To send messages on Mxit is cheaper than sending messages using SMS (Swanepoel, 2011). The way Mxit is affordable may bridge the infrastructure gap by allowing learners to learn at their convenient time without paying more for extra classes.

Mxit may help learners to improve their mathematics marks because they will have access to the best mathematics teachers wherever they are. On Mxit learners can post their mathematics problems to a group wherever they are and at any time and get guidance from Mxit tutors.

With all these features on Mxit, the fact that it is freely available and the potential it has to assist learners to improve their mathematics knowledge and therefore improve their results, it is concerning that learners are not taking advantage of this technology. In order to address this problem at schools in rural areas, this research established the factors and conditions that will promote the use of instant messaging for learning in the rural public high schools in the Limpopo Province of South Africa. The main aim of this study was to investigate factors that influence the adoption of instant messaging for learning mathematics in rural public schools in Limpopo Province. To realize the aim of this study the objectives below were formulated:

- To determine learners' awareness of instant messaging for learning mathematics in rural public schools.

- To identify relative advantages of adopting instant messaging for learning mathematics in rural public schools in Limpopo Province.

- To determine compatibility of instant messaging with the culture of learning mathematics in rural public schools in Limpopo Province. 
- To explore the complexity of using instant messaging by learners for learning mathematics in rural public schools in Limpopo Province.

- To identify observable benefits of adopting instant messaging for learning by the learners in rural public schools in Limpopo Province.

\section{Theoretical Framework}

Good use of theory aids in designing the study more effectively, as well as being useful to take a broad view of the end results (Kogg, 2002). According to Shi (2011) diffusion of innovation (DOI) is the most well-known theory and model in technology adoption. Rogers (1995) defines diffusion of innovation as the process by which an innovation is communicated among the member of a social system through certain channels over time.

Rogers (2003) defined innovation as the creation of a new technical product, application method, scientific knowledge, and tool that facilitates problem solving. Different adopters assess and perceive innovation in various ways. Dr Math on Mxit is a recent innovation application which offers the learners the ability to solve their mathematics problems without any difficulties. Therefore, this research used diffusion of innovation theory as an underpinning theory. These five constructs that have an impact on the rate of adoption according the DOI are Relative advantage, Compatibility, Complexity, Trialability and Observability. In this study we have added awareness which was added by Ramavhona (2014) in his study of Internet Banking in South African rural areas.

Relative advantage: is the degree to which an innovation is perceived as better than the idea it replaces (Rogers, 1995). It should be noted that the relative advantage of an innovation is closely associated with an individual perception. Whether a user believes the innovation as advantageous is more important than whether an innovation has an objective advantage over the precedent idea (Shi, 2011).

The greater the perceived relative advantage of an innovation, the more rapid its adoption will be (Al-Jabri \& Sohail, 2012). Dr Math on Mxit offers learners greater control to ask questions in order to get assistance with their mathematics homework (Haskins \& Botha, 2013). Learners can access Mxit on their cell phone to learn mathematics at their convenient time (Butgereit \& Botha, 2012). With all this relative advantage of instant messaging, it would be expected that learners from rural public schools would be likely to adopt this service. We therefore hypotheses that:

Hypothesis 1: Relative advantage of instant messaging will positively influence the use of instant messaging for learning in South African rural public schools.

Compatibility: is the degree to which an innovation is perceived as being consistent with the existing values, past experiences, and needs of potential adopters (Rogers, 1995). An idea that is incompatible with the values and norms of a social system will not be adopted as rapidly as an innovation that is compatible. The adoption of an incompatible innovation often requires the prior adoption of a new value system which is a relatively slow process (Al-Jabri \& Sohail, 2012). A study conducted by Gerrard and Cunningham, (2003) shows that compatibility is an important factor which influences the adoption of innovation. The youth are already using instant messaging for soccialising. We therefore hypotheses that: 
Hypothesis 2: Compatibility of instant messaging with the culture of learning will positively affect learners to use instant messaging for learning in South African rural public schools.

Complexity: is the degree to which an innovation is perceived as difficult to understand and use (Rogers, 1995). New ideas that are simpler to understand are adopted more rapidly than innovations that require the adopter to develop new skills and understandings (Al-Jabri \& Sohail, 2012). Instant messaging, specifically Dr Math on Mxit, has a user-friendly interface which would give learners a perception that instant messaging services are less complex to use for learning; thus it would promote learners intention to adopt these innovations (Butgereit, 2011). The adoption will be less likely if the innovation such as instant messaging is considered as complicated to use and not user friendly (Rogers, 1983:230). We therefore hypotheses that:

Hypothesis 3: Complexity will negatively affect learners to use instant messaging for learning in South African rural public schools.

Trialability: is the degree to which an innovation may be experimented with within a limited basis (Rogers, 1995). The theory suggests that, innovations that are experimented with will be likely to be adopted more quickly than innovations that are not tried. This is due to the decreased uncertainty gained by experimenting (Shi, 2011). An innovation that is trialable represents less uncertainty to the individual who is considering it for adoption, who can learn by doing (Al-Jabri and Sohail, 2012). The research conducted by Tan and Teo (2000) indicates that if the users are given the opportunity to try an innovation, it would reduce the apprehension towards the usage of the new innovation. The study conducted by Hernandez and Mazoon (2007), showed that trialability has a significant influence on new technology adoption. We therefore hypotheses that:

Hypothesis 4: Trialability of instant messaging will positively influence learners to use instant messaging for learning in South African rural public schools.

Observability: is the degree to which the results of innovations are visible to others (Rogers, 1995). This observability stimulates discussion around the innovation as the peer group requests evaluation information about the innovation. The theory suggests that, the more individuals see observable results of an innovation, the more they are likely to adopt it (Shi, 2011). We therefore hypotheses that:

Hypothesis 5: Observability will affect learners' behavior towards using instant messaging for learning in South African rural public schools.

Awareness: is the degree to which the users are aware of the new innovation, know how it works and what its objectives are. Shi (2011) indicates that lack of awareness among people can become a barrier to the adoption of an innovation. The study conducted by Al-Jabri and Sohail (2012), shows that awareness plays an important role in influencing the adoption of the innovation. We therefore hypotheses that:

Hypothesis 6: Awareness of instant messaging for learning affects the adoption and use of instant messaging positively in South Africa rural public schools. 


\section{Research Model}

The DOI theory constructs were used to develop the research model in Figure 1. The Diffusion of Innovation Theory supports the objective of the research which is to investigate factors that will influence the adoption of instant messaging for learning mathematics in rural public schools in Limpopo Province.

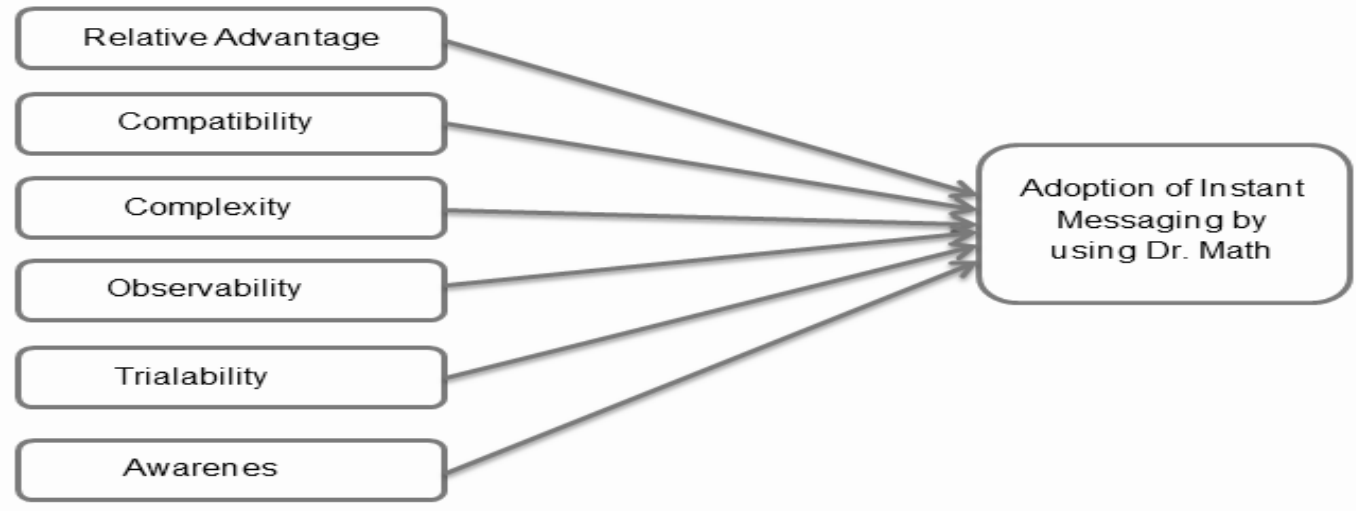

Figure 1. Modified Diffusion of Innovation Theory (Rogers, 1995)

This research therefore used all five constructs of diffusion of innovation theory and awareness because they provides an important framework to support the research.

\section{Research Design}

Data was collected from learners and educators in Limpopo Province. This research adopted the quantitative research approach. A technique for quantitative data collection includes a survey or experiments (Neuman, 2007).

\section{Participants}

The sample of the study consinst learners from public schools in the rural areas in Limpopo province. According to Babbie (2007), purposive sampling is a non-probability sampling method in which participants are selected based on the personal judgement of the researcher, concerning how they can add value to the research problem (Babbie, 2007; Mokwena, 2011). The judgmental sampling was use to select public schools in South African rural areas in Limpopo Province, Vhembe district. Therefore, the researcher used judgmental sampling by selecting schools with low performance in mathematics as a criterion. In this study purposive sampling method was applied to select the learners and educators to participate in this study.

\section{Data Collection Procedure}

A close-ended questionnaire survey technique was used to collect data.. Questionnaires were couriered and delivered by hand to the school principal or head of department (HOD) at schools. Sixty-four questionnaires were sent through courier services to four schools. Three hundred and thirty-six questionnaires were hand delivered. 
In total, 400 questionnaires were distributed to 13 schools in Vhembe district in the rural areas in Limpopo Province in South Africa. Of the 400 questionnaires distributed, 288 were returned. Of the 288 responses received 86 were not usable. According to Babbie (2005), the researcher must not sit back and relax; instead the researcher should record all the varying rates of returns of questionnaire. In this research the returns of the questionnaires which were hand-delivered were simple to trace because those questionnaires were collected the same day or the following day. For the questionnaires that were sent via courier services, the researcher telephoned the school's principals to check whether the questionnaires had been delivered. Questionnaires delivered via courier services were collected a week after from the delivery date.

\section{Results Analysis and Discussion}

Before starting with data analysis, screening was performed and after that data preparation was conducted by means of coding and editing the collected data. Editing is the process of making sure that the questionnaires were completed by the respondents according to instructions (McDaniel \& Gates, 2002:464; Mokwena, 2011). In this research, the coding, editing and capturing of data was done by using Microsoft Excel and then uploaded on IBM SPSS

Statistics 20 for analysis

IBM SPSS Statistics 20 was used to analyze and to describe the demographics of the collected data from the participants.

Table 2. Demographic data

\begin{tabular}{|l|r|r|}
\hline \multicolumn{1}{|c|}{ Characteristics } & Frequency & Percent (\%) \\
\hline Status & 188 & $93.1 \%$ \\
Learners & 14 & $6.9 \%$ \\
\hline Educators & & $48.5 \%$ \\
Male & 98 & $51.5 \%$ \\
Female & 104 & \\
\hline Age & & $88.6 \%$ \\
17 to 20 years & 179 & $4.0 \%$ \\
21 to 30 years & 8 & $1.0 \%$ \\
31 to 40 years & 2 & $0.5 \%$ \\
41 to 50 years & 1 & $5.4 \%$ \\
51 to 60 years & 11 & $0.5 \%$ \\
61 to 65 years & 1 & \\
Nell phone experience & & \\
1 to 2 years & 3 & $1.5 \%$ \\
3 to 4 years & 33 & $16.3 \%$ \\
5 to 6 years & 57 & $28.2 \%$ \\
7 or more & 37 & $18.3 \%$ \\
Yes & 72 & $35.6 \%$ \\
\hline No & & \\
\hline
\end{tabular}

As indicated in Table 2, the demographic status of the respondents shows that [188 (93.1\%)] were learners and [14 (6.9\%)] were educators. Ninety-eight [98 (48.5\%)] of the respondents were males and one hundred and four [104 $(51.5 \%)]$ were females. The demographic age group of the respondents shows that the 17 to 20 years age group dominated with [179 (88.6\%)], followed by 51 to 60 years age group with [11 (5.4\%)], then 21 to 30 years age group with [8 
$(4.0 \%)]$, then 31 to 40 years age group with [2(1\%)], then 41 to 50 years age group with $[1(0.5 \%)]$ and finally the 61 to 65 years age group with [1 (0.5\%)]. In terms of using cell phone, [72 (35\%)] had 7 or more years' experience of using a cell phone, followed by [57 (28\%)] who had 3 to 4 years' experience of using cell phone, followed by [37 (18\%)] who had 5 to 6 years' experience, [33 (16.3\%)] respondents had 1 to 2 years' experience of using a cell phone and finally [3 (1.5\%)] did not have experience of using a cell phone. A [166 (82.2\%)] respondents, indicated that their cell phones can connect to the Internet and thirty six $[36(17.8 \%)]$ had cell phones that do not connect to the Internet.

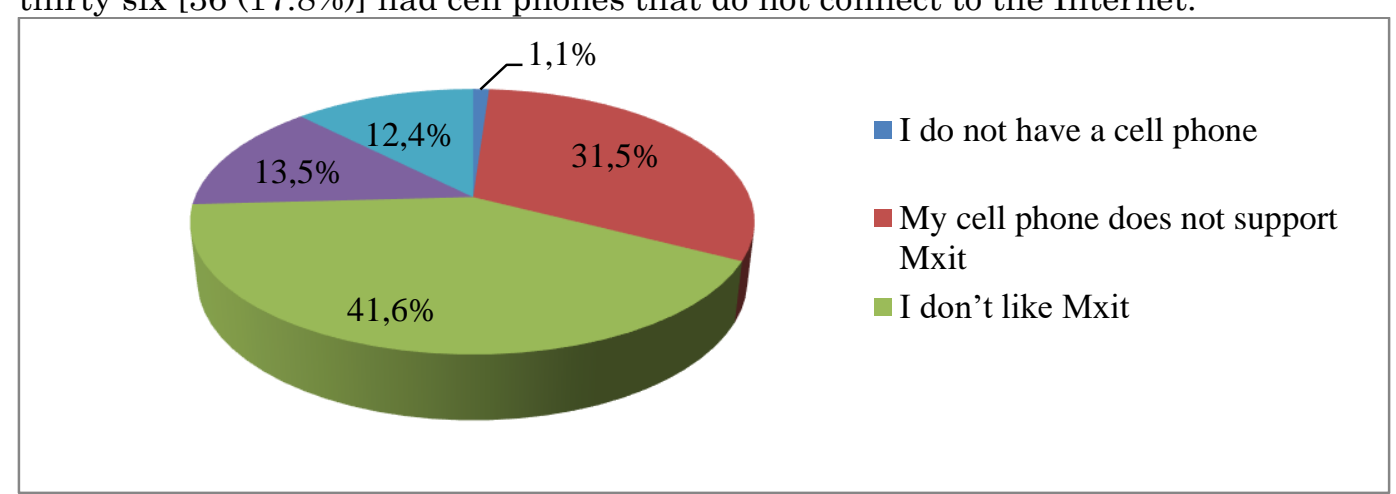

Figure 2. Reason for not using Mxit

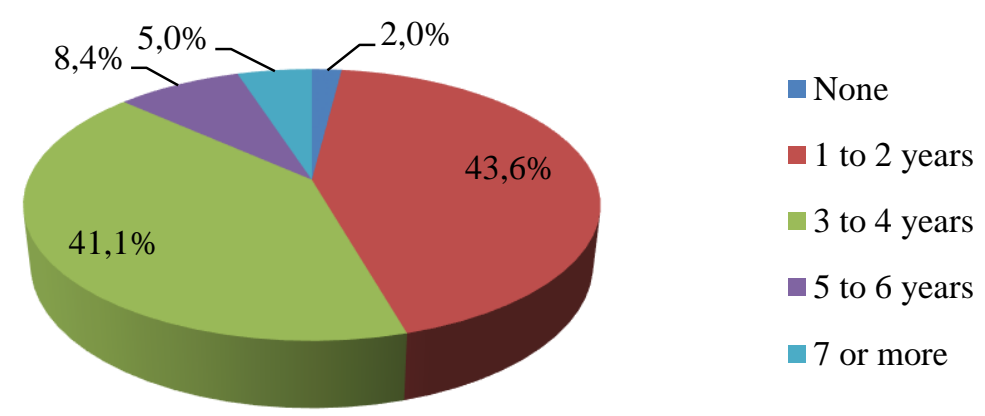

Figure 3. Experience using Mxit

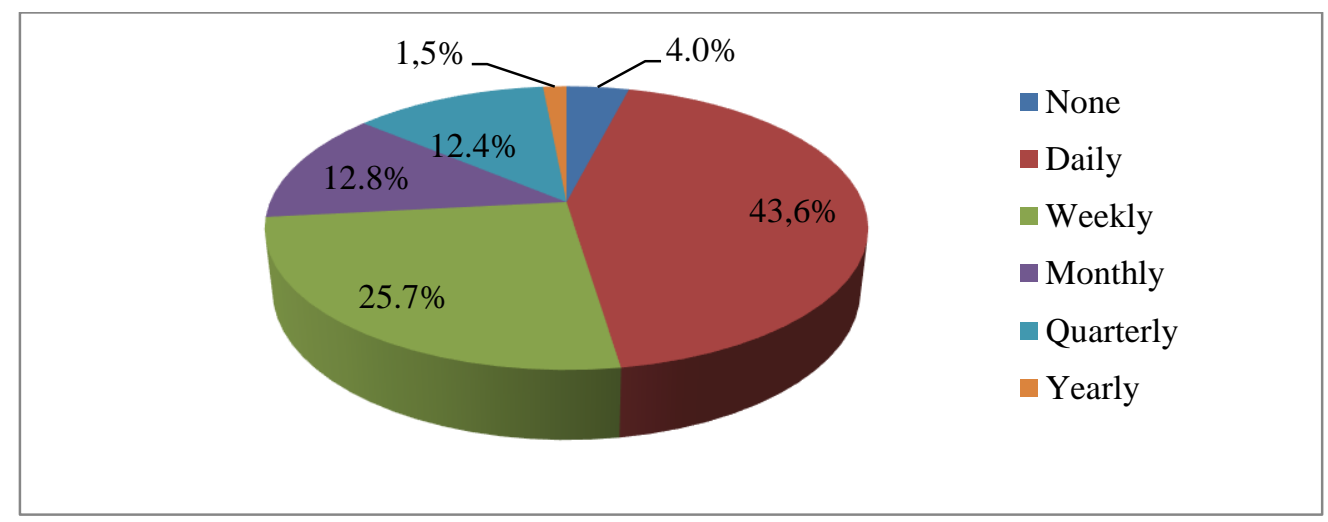

Figure 4. Mxit usage frequency 
Respondents experience using Mxit are presented as follows: Most of the respondents [114 (56.4\%)] showed that they have used Mxit compared to eightyeight [88 (43.6\%)] who have never used Mxit. As to the reasons why the respondents are not using Mxit, Figure 1, shows that majority of respondents [37 (41.6\%)] indicated that they do not like Mxit, [28 (31.5\%)] stated that their cell phones do not support Mxit, [12 (13.5\%)] respondents said they have not heard of Mxit, [11 (12.4\%)] respondents said they do not feel safe using Mxit and [1 (1.1\%)] respondent does not have a cell phone. This means $54.6 \%$ of learners who used Mxit are likely to adopt Mxit for learning because they have seen the relative advantage of using Mxit and 43.6 may adopt Mxit for learning later after have been trained. As indicated in Figure 2, the experience of using Mxit was distributed as follows: [88 (43.6\%)] respondents had no Mxit experience, compared to [83 (41.1\%)] respondents, who had 1 to 2 years of experience, [17 (8.4\%)] respondents had 3 to 4 years of experience, [10 (5.0\%)] respondents had 5 to 6 years of experience and [4 (2.0\%)] respondents had 7 or more years of experience.

As indicated in Figure 3, most of the respondents [88 (43.6\%)] has showed that they do not use Mxit at all while [52 (25.7\%)] of the respondents showed that they use it daily, [26 (12.8\%)] of the respondents showed that they used it weekly, [25 (12.4\%)] of the respondents showed that they used it monthly, [3 (1.5\%)] respondents showed that they used it quarterly and [8 (4.0\%)] respondents showed that they used it yearly. The majority of respondents [106 (95.5\%)] indicated that they use Mxit for communicating with friends and family, while [5 (4.5\%)] indicated that they use Mxit for learning. This research is supported by the study previously conducted by Butgereit and Botha (2012), which presented that most youth have experience of using Mxit on their cell phones.

Most of the respondents [194 (96.0\%)] showed that they have never used Dr Math on Mxit for learning compared to four [8 (4.0\%)] respondents who showed that they have used Dr Math on Mxit for learning. This study is contrary to the previous research conducted by Robbins (2013) that indicated that most learners have experience using Dr Math. [6 (75\%)] respondents who used Dr Math indicated that they learned about it from newspapers or magazines and [2 (25\%)] respondents who used Dr Math indicated that they learned about it from friends or relatives. One hundred and eighty-three [183 (94.3\%)] respondents who never used Dr Math indicated that they have not heard about it, [4 (2.1\%)] respondents indicated that there is no need for Dr Math, they prefer learning in the classroom, [3 (1.5\%)] respondents indicated that it takes more of their time; [2(1.0\%)] respondents indicated that it does not help them with learning; and [2(1.0\%)] respondents indicated that the cost of using Dr Math is high. This means that there is no enough awareness about the use of Dr Math for learning in the rural public schools.

This research used a regression model to determine the degree to which relative advantage, compatibility, complexity, trialability, observability and awareness can impact the adoption of Mxit for learning in South African rural public schools. This model shows the degree to which independent variables impact the dependent variable.

Table 3. Regression analysis model results 


\begin{tabular}{|c|c|c|c|c|c|}
\hline \multirow{2}{*}{ Model } & \multicolumn{2}{|c|}{$\begin{array}{l}\text { Unstandardized } \\
\text { Coefficients }\end{array}$} & \multirow{2}{*}{\begin{tabular}{|c|}
$\begin{array}{c}\text { Standardize } \\
\mathrm{d} \\
\text { Coefficients }\end{array}$ \\
Beta \\
\end{tabular}} & \multirow[t]{2}{*}{$\mathrm{t}$} & \multirow[t]{2}{*}{ Sig. } \\
\hline & B & Std. Error & & & \\
\hline $\begin{array}{l}\text { (Constant) } \\
\text { Relative Advantage } \\
\text { Compatibility } \\
\text { Complexity } \\
\text { Trialability } \\
\text { Observability } \\
\text { Awareness }\end{array}$ & $\begin{array}{r}1.057 \\
.092 \\
-.077 \\
.123 \\
.295 \\
.283 \\
.280 \\
\end{array}$ & $\begin{array}{r}.448 \\
.157 \\
.143 \\
.115 \\
.078 \\
.068 \\
.066\end{array}$ & $\begin{array}{r}.058 \\
. .053 \\
.076 \\
.270 \\
.267 \\
.306 \\
\end{array}$ & \begin{tabular}{r|}
2.357 \\
.586 \\
-.540 \\
1.066 \\
3.787 \\
3.689 \\
4.228 \\
\end{tabular} & $\begin{array}{l}.019 \\
.558 \\
.590 \\
.288 \\
.000 \\
.000 \\
.000\end{array}$ \\
\hline \multicolumn{6}{|c|}{ Dependent Variable: Adoption of Mxit } \\
\hline R Square & .237 & & F. Change & & 10.071 \\
\hline Adjusted R Square & .213 & & Sig. & & $.000^{b}$ \\
\hline
\end{tabular}

The outcomes of the regression analysis from Table 3 , showed that the predictor variables in this research account for at least $21.3 \%$ of the variance in the Mxit adoption for learning (Adjusted R Square =.213). The results continue to indicate that trialability (Beta $=.270$, Sig. $=.000$ ), observability (Beta $=.283$, Sig. $=.00)$ and awareness $($ Beta $=.306$, Sig. $=.000)$ are the main predictors of using Mxit for learning. Then compatibility (Beta $=-.053$, Sig. $=.590$ ), relative advantage (Beta $=.058$, Sig. $=.558)$ and complexity (Beta $=.076$, Sig. $=.288)$ were found not significant predictors of the adoption of Mxit for learning in South Africa public schools. This result means that the awareness contributes to (.306) positive changes in the adoption of Mxit for learning in rural public schools followed by trialability which contribute (270) positive changes in the adoption of Mxit for learning in South African public schools. Therefore, the Department of Education should prioritise trialability and awareness to promote the adoption of Mxit for learning. The Department of Education should provide more awareness regarding the use of Mxit for learning and encourage educators and learners to try Mxit for learning in order draw the benefits it has for learning. The regression analysis was also used to look at the significant of $($ sig<.000) so that it may be used to draw a reliable conclusion and make recommendation for the adoption of Mxit for learning.

The results obtained from this research show that the learners in South African rural public schools are unclear about the relative advantages of using Mxit for learning. The correlation analysis results revealed that relative advantage has a weak positive relationship with the adoption of Mxit for learning $\left(\mathrm{r}=.263^{* *}, \mathrm{p}<\right.$. 001). When the relative advantage of using Mxit for learning improves, more learners in South African rural public schools will intend to adopt Mxit for learning. Regression analysis results showed that relative advantage of Mxit for learning is not significant (Beta=. 058, Sig. =.558). These results vary from the results obtained from the study previously conducted by Haskins \& Botha (2013), which identified relative advantage as a vital factor that influences the adoption of instant messaging using Dr Math on Mxit for learning.

The results drawn from this research showed that the learners in South African rural public schools are uncertain about the complexity of the use of Mxit for learning. The correlation analysis results showed that the complexity has a weak positive relationship with the intention to adopt Mxit for learning ( $\mathrm{r}$ $=.237^{* *}, \mathrm{p}<.001$ ). The regression results shown that the complexity is not 
supported as the predicting elements to the adoption of Mxit for learning (Beta $=.076$, Sig. $=.288$ ).

The results derived from this research show that the learners in South African rural public schools perceived that trying Mxit for learning can be beneficial for them to adopt Mxit for learning. The majority of respondents (88.5\%) indicated that being able to try out Mxit will be important for them to make the decision to use Mxit for learning, while (88.9\%) respondents indicated that they want to try Mxit on a trial basis to check the improvement in their mathematics results. The correlation analysis results show that trialability of Mxit for learning has a strong positive relationship with the adoption of Mxit for learning $(\mathrm{r}=.608, \mathrm{p}<.001)$. The regression analysis results indicate that reliability of Mxit for learning has a significant $($ Beta $=.270$, Sig. $=000)$ predicting factor in the adoption of Mxit for learning in South African rural public schools. Therefore, trialability was supported as an important predictor of adoption of Mxit for learning in South Africa rural public schools.

Based on the results of this study, the learners in South African rural schools are unclear about the observable benefits and advantages of using Mxit for learning. The correlation analysis results showed that the observability shows a strong positive relationship with the intention of adopting Mxit for learning $(\mathrm{r}=.698, \mathrm{p}<.001)$. The regression analysis results showed that the observability is supported as the predicting element to the adoption of Mxit for learning (Beta $=.267$, Sig. $=000$ ). This study is in support with the study previously conducted by Robbins (2013) which indicated that observable benefits for using Dr Math influence the adoption because it makes it easy to understand what the teacher taught in the class.

The findings of this study indicate that the respondents are not aware of Mxit for learning in South African rural public schools. The majority of respondents $(44.0 \%)$ indicated that there is no enough awareness about learning mathematics using Mxit, (64.4\%) respondents are not aware that Mxit is used for learning Mathematics and (33.3) respondents are not aware of using Mxit for learning and its benefits. The correlation analysis results show that awareness of Mxit for learning has a strong positive relationship to the adoption of Mxit for learning $(\mathrm{r}=.779, \mathrm{p}<.001)$. The regression analysis results indicated that awareness of Mxit for learning has a significant (beta $=.306$, Sig. $=.000$ ) predicting factors in the adoption of Mxit for learning in South Africa rural public schools. Therefore, awareness is supported as a predicting factor for the adoption of Mxit in South African public rural schools. The more learners start being aware of this innovation, the more likely they are to adopt Mxit for learning.

In this study, six hypotheses were formulated. Beta and significance of the regression analysis model were used to test hypothesis by regressing each independent variable against the dependent variable which is the adoption of Mxit for learning.

Table 4. Hypothesis acceptance and rejection test notes

\begin{tabular}{|l|l|l|l|l|}
\hline Hypothesis & Variables & Beta & P - Value & Notes \\
\hline Hyp1 & Relative Advantage & .058 & .558 & Not Supported \\
\hline Hyp2 & Compatibility & -.053 & .590 & Not Supported \\
\hline Hyp3 & Complexity & .076 & .288 & Not Supported \\
\hline Hyp4 & Trialability & .270 & .000 & Supported \\
\hline Hyp5 & Observability & .267 & .000 & Supported \\
\hline
\end{tabular}




\begin{tabular}{|l|l|l|l|l|}
\hline Hyp6 & Awareness & .306 & .000 & Supported \\
\hline
\end{tabular}

The finding from this research indicates that the intention to adopt Mxit for learning can be projected by trialability, observability and awareness but not by relative advantage, compatibility and complexity.

Relative advantage (Hyp1) is not supported. The hypothesis one stated that relative advantage affects the intention to adopt and use Mxit for learning in South African rural public schools. The rejection of this variable as the possible predictor of the adoption or use of Mxit for learning was due to the fact that most learners were unsure about the advantages of using Mxit for learning because majority of respondents (96.0\%) had never used Mxit for learning. The relative advantage of using Dr Math on Mxit for learning was not realised because most respondents do not know about this readily available cell phone application. Learners therefore, do not know these benefits, such as learning wherever they are, during their convenient time, asking questions regarding their mathematics problems and receiving guidance from the tutos on how to solve their mathematics problems by using Dr Math on Mxit for learning.

Compatibility (Hyp2) is not supported. The compatibility variable is not supported as one of the potential predictors of the adoption of Mxit for learning in South African rural public schools. Based on the results, the majority of respondents do not know about using Mxit for learning and they were uncertain about the compatibility of using Mxit for learning with their cultural way of learning. The correlation results show that compatibility has a weak positive relationship to the intention of adopting Mxit for learning $\left(\mathrm{r}=.240^{* *}, \mathrm{P}<.001\right)$. When learners start identifying any compatibility of using Mxit with the cultural way of learning in South African rural public schools, the more learners will be likely to adopt Mxit for learning.

Complexity (Hyp3) is not supported. It has been shown in this research that complexity has a negative effect on the adoption of Mxit for learning in rural public schools. Rogers (1995), claims that if the latest innovation is difficult to use, then would be less likely to be adopted faster. The more learners use Mxit for learning and understand how it works and feel comfortable with it, the chances of learners adopting Mxit for learning in South African rural public schools will improve.

Trialability (Hyp4) is supported. It has been shown in this research that trialability of Mxit for learning may positively promote the adoption of Mxit for learning in South African rural public schools. Even though the scope is not the same, the support is in line with the outcome from the study conducted by Hernandez \& Mazoon (2007) which highlights that trialability has an important influence on the adoption of the new technology. Trialability of instant messaging for learning may improve the economy in the future because it will alleviate the gap of scarce skills. This may assist developing countries to improve their standard of education. The correlation results show that trialability has a strong positive relationship with the intention to adopt Mxit for learning $\left(\mathrm{r}=.608^{* *}, \mathrm{P}<.001\right)$. The more Mxit for learning becomes tested, the more learners would possibly adopt Mxit for learning.

Observability (Hyp5) is supported. The hypothesis five states that observability influences the intention to adopt and use Mxit for learning in South African rural public schools. The correlation results has shown that observability has a strong positive relationship with the intention of adopting 
Mxit for learning $\left(\mathrm{r}=.698^{* *}, \mathrm{P}<.001\right)$. The more observable benefits on the use of Mxit for learning, the more learners in rural public schools would be likely to adopt Mxit for learning.

Awareness (Hyp6) is supported. The hypothesis six states that awareness of Mxit for learning will positively influence the adoption and use of Mxit for learning in South African rural public schools. The more learners are aware of Mxit for learning in South African rural public schools, the more they are likely to adopt Mxit for learning. The regression results showed awareness as one of the important predictors to influence the adoption of Mxit for learning in South African rural public schools. Research conducted by Polatoglu and Erkin (2001) supports this by stating that users' knowledge has an influence on the adoption of new technology.

\section{Conclusion}

This study sought to answer the following research problem: Why there is a significantly high failure rate of mathematics in the South Africans rural public schools, while there is this feature on Mxit and the potential it has to assist learners to improve their mathematical knowledge and therefore, improve their results, why learners are not taking advantages of this readily available technology. This question may apply to any country where technology is available, but it is not being adopted or used. The general conclusions of this research grounded on the outcome presented in the section above are as follows.

- The study found that most of the learners in South African rural public schools have cell phones which have an Internet connection and they use Mxit on a daily basis. This was found as the important factor to adopt Mxit for learning.

- This study found that learners are not aware of any benefits that Mxit has for learning to improve their mathematics results.

- The findings of this study indicated that most respondents in South African rural public schools have never used Dr Math for learning mathematics because they have never heard about it.

- The finding of this research indicates that there is no enough awareness of using Mxit for learning.

- The factors such as trialability, observability and awareness were found to have an important influence on the adoption of Mxit for learning in South African rural public schools. However, relative advantage, compatibility, and complexity were found not to be important factors in influencing the adoption of Mxit for learning in South African rural public schools.

- It was found that most of the respondents would like to try Mxit for learning on a trial basis to see any effects it may have on their marks.

- Findings show that the participants are likely to adopt Mxit for learning in South African rural public schools.

In this study, conclusions were drawn from demographic details, Mxit and Dr Math usage and experience of the respondents and psychological elements which may influence learners to adopt instant messaging for learning using Dr Math on Mxit. Lack of awareness for learning using Dr Math on Mxit was found to be the greatest challenge which hampered learners in South African rural public schools to adopt instant messaging for learning using Dr Math on Mxit. A hypothesis test was conducted; three hypotheses were supported and the other three hypotheses were rejected during regression analysis. The trialability, 
observability and awareness were found to have a significant influence on the adoption of instant messaging for learning using Dr Math on Mxit in South African rural public schools.

\section{Disclosure statement}

No potential conflict of interest was reported by the authors.

\section{Notes on contributors}

Nkhangweni Lawrence Mashau - Tshwane University of Technology, South Africa.

Sello Nicolas Mokwena - Tshwane University of Technology, South Africa.

\section{References}

Al-Jabri, I.B., \& Sohail, M.S. (2012). Mobile Banking Adoption: Application of Diffusion of Innovation theory. Vol 13. No4. Saudi Arabia: College of Industrial Management.

Babbie, E. (2007). The practice of social research. (11th edition). Belmont: Wadsworth.

Beger, G., \& Sinha, A. (2012). South Africa Mobile Generation: Study on South AfricaYoung people on mobiles. New York: Unicef.

Bryman, A. (2001). Social Research Methods. New York: Oxford University Press.

Butgereit, L. (2009). How Dr Math reaches Pupils with Competitions and Computer Games by using Mxit. Pretoria: IST-Africa.

Butgereit, L. (2011). Seven Characteristics of a Successful Virtual Volunteering Platform. South Africa: IST-Africa.

Butgereit, L.L., \& Botha, R.A. (2011). A Lucene stemmer for Mxit lingo. South Africa: Annual Conference on World Wide Web Applications.

Butgereit, L., \& Botha R.A. (2012). Automated Topic Spotting Provides Added Efficiency in a Chat Based Tutoring Environment. South Africa: IST-Africa.

Casey, M., \& Hoehler, J. (2013). Engagement with mobile application. Johannesburg: Deloite \& Touche.

Cooper, R.C., \& Schindler, P.S. (2003). Business Research Methods. New York: McGraw-Hill.

Country report South Africa (2013). General Education System Quality Assessment. South Africa: 978-1-4315-1866-1.

Dewitt, D., Siraj, S., \& Alias, N. (2014). Collaborative mLearning: A Module for Learning Secondary School Science. Malaysia: International Forum of Educational Technology \& Society IFETS).

Erasmus, P. (2013). Relationship between emotional intelligence, study orientation in maths and maths achievement of middle adolescent boys and girls. South Africa: North West. Proceedings of the Global Summit on Education (GSE2013).

Gerrand, P., \& Cunningham, J.B. (2003). The diffusion of Internet banking among Singapore consumers. International Journal of Bank Marketing. 
Graham, S.E., \& Provost, L.E. (2012). Mathematics achievement gaps between suburban learners and their rural and urban peers increase over time. Issue brief NO. 52. Durham: The Carsey Institute at the Scholars' Repository.

Graven, M.H. (2013). Poverty, inequality and mathematics performance: the case of South Africa's post-apartheid context. South Africa: Grahamstown. Springer.

Haskis, B., \& Botha, A. (2013). Identify Tag Word Counterparts for Dr Math. South Africa: AA AI Spring Symposium.

Hernandez, J. \& Mazzon, J. (2007). Adoption of internet banking: proposition and implementation of an integrated methodology approach. Marketing, 25(2).

Hofstee, E. (2011). Constructing a Good Dissertation. Sandton. Interpark Books. Junco, R., \& Cotton, S.R. (2010). Perceived academic effects of instant messaging use. USA: Elservier.

Kim, H., Lee, M., \& Kim, M. (2014). Effects of Mobile Instant Messaging on Collaborative Learning Processes and Outcomes: The Case of South Korea. South Korea: International Forum of Educational Technology \& Society (IFETS).

Kogg, B. (2002). The role of theory in case study research. PhD course in Research methodology 2002-12-08.

Kumar, A., Tewari, A., Shroff, G., Chittamuru, D., Kam, M., \& Canny, J. (2010). An Exploratory Study of Unsupervised Mobile Learning in Rural India. USA: Human-Computer Interaction Institute.

Kwapisz, J.R., Weiss, G.M., \& Moore, S.A. (2010). Activity Recognition using Cell phone Accelerometers. Volume 12. Issue 2. USA: SIGKDD Explorations.

Limpopo Basic Education (2014). School performance report Limpopo. Limpopo: Basic Education.

Limpopo Department of Education (2014). Strategic Performance Plans. Polokwane: Limpopo Department of Education.

Lumandi, M.W. (2014). Reversing the Trend of Dismal Perfomance in Disadvantaged Schools: A Curriculum Evaluation exercise. Rome-Italy: MCSER.

McDaniel, C., \& Gates, R. (2002). Marketing Research. Singapore: South-Western.

Maphalala, M.C., \& Nzama, M.V. (2014). The Proliferation of Cell phones in High Schools: The Implications for the Teaching and Learning Process. Rome-Italy: MCSER Publishing.

Mokwena, S.N. (2011). Factors influencing the acceptance and use of a school administration and management system in South African high schools. UnpublishedPhD thesis. Pretoria: Tshwane University of technology.

Mouton, J. (2001). How to succeed in your Master's and Doctoral Studies: A South African Guide and Resource Book. (13th edition). Pretoria: Van Schaik.

Neuman, W.L. (2007). Basic of Social Research, Qualitative and Quantitative Approaches. (2nd ed). Boston: Person Education, Inc.

Ojose, B. (2011). Mathematics Literacy: Are We Able To Put The Mathematics We Learn Into Everyday Use? Vol. 4 USA: Redlands.

OXFORD South Africa Concise Dictionary (2010). South Africa: Megan Hall.

Quan-Haase, A., \& Young, A.L. (2010). Used and Gratification of Social Media: A Comparison of Facebook and Instant Messaging. USA: Bulletin of Science, Technology and Society. 
Reed, M., Jotischky, N., Newman, M., Mbongue, T., \& Escofet, G. (2014). Africa Telecoms Outlook2014, Maximizing digital service opportunities. London: Informa telecoms \& media.

Robbins, B. (2013). Extending the Dialogue: Interactional and Multimodal Strategies in Synchronous Mobile Mathematics Tutoring on MXit. Cape Town: University of Cape Town.

Rogers, E.M. (1995). Diffusion of Innovation, (4th edition). New York: Free Press.

Rogers, E.M. (1983). Diffusion of Innovations. New York: Free press.

Roux, K., \& Dalvit, L. (2014). Mobile Women: Investigating the Digital Gender Divide in Cell phone Use in South Africa Rural Area. South Africa: 401-416.

Ruan, Q. (2013). Can Instant Messaging Platform QQ Help Solving the Deficiency of EFL Learners' Critical Literacy in China? China: Atlantis Press.

Sekaran, U. (2003). Research Methods for Business: A Skill-Building Approach, (4th edition). New York: John Wiley \& Sons, Inc.

Shambare, R., Rugimbana, R., \& Sithole, N. (2012). Social networking habits among learners. African Journal of Business Management. Pretoria: Academic Journals, 6(2):578-786.

Shi, X. (2011). Exploring factors that hinder the adoption of Mobile Services in China A qualitative user analysis with special focus on mobile financial services. University School of economics: Aalto.

South Africa mobile report (2014). A Survey of Desktop User's Attitude and Uses of Mobile Phone. South Africa: iab.

Swanepoel, T. (2011). Cybersex and Addiction: A Quantitative Examination of the Use of Mxit Among Adolescents in South Africa. South Africa: UCT

Tachie, S.A., \& Chireshe, R. (2013). Higher Failure Rate in Mathematics Eximanition in Rural Senior Secondary Schools in Mthatha District, Eastern Cape: Learners' Attributions. South Africa: Kamla-Raj.

Tan, M., \& Teo, T.S.H. (2000). Factors influencing the adoption of Internet banking. J.Assoc. Info. Syst. 1(5): 22-38.

Tewari, D.D. (2014). Is Matric Math a Good Predictor of Student's Perfomance in the First Year of University Degree? A Case Study of Faculty of Management Studies, University of KwazuluNatal, South Africa. South Africa: Kamla-raj.

Vosloo, S. (2008). Using Mxit to learn. [Online] Available from: http://www.thoughtleader.co.za/stevevosloo/2008/01/18/using-mxit-to-learn/. [Accessed 23 April 2015].

Wang, W., Hsieh, J.P., \& Song, B. (2010). Understanding User Satisfaction of Instant Messaging Usage: An Empirical Study. China: Natural Science Foundation.

Welman, J., \& Kruger, S. (2005). Research Methodology. Cape Town: Oxford University Press. Yin, R.K. (2011). Qualitative research from start to finish. New York, NY: The Guilford Press. 